\title{
Spatial and temporal variability of particulate polycyclic aromatic hydrocarbons in Mexico City
}

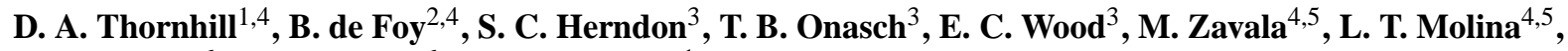 \\ J. S. Gaffney ${ }^{6}$, N. A. Marley ${ }^{6}$, and L. C. Marr ${ }^{1}$ \\ ${ }^{1}$ Dept. of Civil and Environmental Engineering, Virginia Polytechnic Institute and State University, Blacksburg, VA, USA \\ ${ }^{2}$ Dept. of Earth and Atmospheric Sciences, Saint Louis University, St. Louis, MO, USA \\ ${ }^{3}$ Aerodyne Research Inc., Billerica, MA, USA \\ ${ }^{4}$ Molina Center for Energy and the Environment, La Jolla, CA, USA \\ ${ }^{5}$ Massachusetts Inst. of Technology, Cambridge, MA, USA \\ ${ }^{6}$ Dept. of Chemistry, University of Arkansas, Little Rock, AR, USA
}

Received: 17 October 2007 - Published in Atmos. Chem. Phys. Discuss.: 9 November 2007

Revised: 19 May 2008 - Accepted: 19 May 2008 - Published: 23 June 2008

\begin{abstract}
As part of the Megacities Initiative: Local and Global Research Observations (MILAGRO) study in the Mexico City Metropolitan Area in March 2006, we measured particulate polycyclic aromatic hydrocarbons (PAHs) and other gaseous species and particulate properties, including light absorbing carbon or effective black carbon (BC), at six locations throughout the city. The measurements were intended to support the following objectives: to describe spatial and temporal patterns in PAH concentrations, to gain insight into sources and transformations of PAHs and BC, and to quantify the relationships between PAHs and other pollutants. Total particulate PAHs at the Instituto Mexicano del Petróleo (T0 supersite) located near downtown averaged $50 \mathrm{ng} \mathrm{m}^{-3}$, and aerosol active surface area averaged $80 \mathrm{~mm}^{2} \mathrm{~m}^{-3}$. PAHs were also measured on board the Aerodyne Mobile Laboratory, which visited six sites encompassing a mixture of different land uses and a range of ages of air parcels transported from the city core. A combination of analyses of time series, back trajectories, concentration fields, pollutant ratios, and correlation coefficients supports the concept of T0 as an urban source site, T1 as a receptor site with strong local sources, Pedregal and PEMEX as intermediate sites, Pico Tres Padres as a vertical receptor site, and Santa Ana as a downwind receptor site. Weak intersite correlations suggest that local sources are important and variable and that exposure to PAHs and BC cannot be represented by a
\end{abstract}

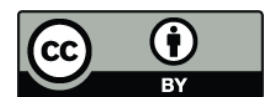

Correspondence to: L. C. Marr (lmarr@vt.edu) single regional-scale value. The relationships between PAHs and other pollutants suggest that a variety of sources and ages of particles are present. Among carbon monoxide, nitrogen oxides $\left(\mathrm{NO}_{\mathrm{x}}\right)$, and carbon dioxide, particulate PAHs are most strongly correlated with $\mathrm{NO}_{\mathrm{x}}$. Mexico City's PAH/BC mass ratio of 0.01 is similar to that found on a freeway loop in the Los Angeles area and approximately 8-30 times higher than that found in other cities. Evidence also suggests that primary combustion particles are rapidly coated by secondary aerosol in Mexico City. If so, their optical properties may change, and the lifetime of PAHs may be prolonged if the coating protects them against photodegradation or heterogeneous reactions.

\section{Introduction}

The Mexico City Metropolitan Area (MCMA) is home to some of the highest measured concentrations of particulate polycyclic aromatic hydrocarbons (PAHs) in the world (Marr et al., 2004; Velasco et al., 2004). PAHs are a class of semi-volatile compounds that are formed during combustion. Many are known or suspected carcinogens. In their condensed form, they are associated mainly with fine particles (Eiguren-Fernandez et al., 2004; Miguel et al., 1998). PAH exposure has been associated with low birth weights (Choi et al., 2006; Tang et al., 2006) and respiratory symptoms in infants (Jedrychowski et al., 2005). Thus, the extremely high concentrations of PAHs in Mexico City may pose a serious health hazard and demand more complete information about

Published by Copernicus Publications on behalf of the European Geosciences Union. 
their spatial and temporal patterns, sources, and transformations in the atmosphere.

Like PAHs, light absorbing carbon, also known as black carbon (BC) or elemental carbon depending on the measurement technique, originates from combustion sources (Bond and Bergstrom, 2006). BC is important because of its suspected toxicity, at least in the form of diesel exhaust particulate matter, and its role in radiative forcing. Coating of $\mathrm{BC}$ by condensation of non light-absorbing material changes throughout the day in Mexico City and alters the particles' optical properties, typically enhancing absorption (Baumgardner et al., 2007).

Aerosol surface area has also been implicated as an indicator of the health impacts of particulate pollution. Toxicology studies suggest that the dose-response relationship is more closely tied to surface area than to mass, number, or size (Brown et al., 2001; Oberdorster, 2000; Stoeger et al., 2006; Tran et al., 2005). Especially for low-solubility particles, surface area may be a more appropriate measure of exposure (Maynard, 2003). Tandem measurements of both PAHs and surface area in laboratory and field experiments have been shown to discriminate between different types of combustion sources and to indicate the degree of particle aging (Bukowiecki et al., 2002; Burtscher et al., 1993; Marr et al., 2004; Ott and Siegmann, 2006; Siegmann et al., 1999).

In April 2003, a multi-national team of scientists conducted an intensive five-week field campaign in the Mexico City Metropolitan Area (MCMA-2003) to contribute to the understanding of air quality problems in megacities (Molina et al., 2007). Measurements of PAHs by three different techniques suggested that PAH concentrations on the surfaces of particles diminish rapidly during the mid-morning hours due to coating by secondary aerosol in the highly photochemically active environment of Mexico City (Dzepina et al., 2007; Marr et al., 2006). However, detailed PAH measurements in 2003 were limited to a single site, so the spatial and temporal variations in their concentrations, which are important from a standpoint of exposure and control, are not known.

In March 2006, an even larger field campaign in Mexico City took place to study air pollution in megacities not only at the local scale, but also at the regional and global scales. The Megacity Initiative: Local and Global Research Observations (MILAGRO) campaign consisted of four components whose goals ranged from providing the scientific basis for policies that would reduce pollutant levels in Mexico City itself to describing the long-range transport of pollution emitted by a megacity. As part of the MCMA-2006 groundbased component focusing on local impacts, we measured particulate PAHs, aerosol active surface area (AS), and other gaseous, particulate, and meteorological parameters at six locations throughout Mexico City. Measurements were situated at the Instituto Mexicano del Petróleo supersite near the city center and on board the Aerodyne Mobile Laboratory (AML). In addition to visiting the supersite, the AML also traveled to five other suburban, exurban, and rural sites (Fig. 1) that encompassed residential, industrial, commercial, undeveloped, and mixed settings.

The objective of this study is to describe the temporal and spatial variations in $\mathrm{PAH}, \mathrm{BC}$, and $\mathrm{AS}$ concentrations in Mexico City. Furthermore, we investigate the relationships between ambient PAHs and other pollutants to gain new knowledge about combustion particles' sources and evolution as they are transported throughout the megacity atmosphere. Transformations are important because they could affect the particles' toxicity, optical properties, and long-range transport impacts. We compare and contrast concentrations in fresh, mixed, and aged emissions by considering a busy downtown location, suburban areas, the city outskirts, and a mountaintop location at the edge of the city. The knowledge gained from the study will provide the scientific basis for the development of risk assessments for exposure to these pollutants in Mexico City and the crafting of control strategies to reduce their emissions and health impacts.

\section{Experimental}

\subsection{Particle surface characterization}

PAHs were measured using real-time sensors (EcoChem PAS 2000 CE) that photoionize particle-bound PAHs by exposing the aerosol to ultraviolet light at a wavelength of $254 \mathrm{~nm}$, which is specific to condensed-phase PAHs. The current generated by the flow of charged particles is then measured. The analyzer produces a semi-quantitative estimate of total PAHs adsorbed on particles' surfaces at 10 -s resolution with a detection limit of $1 \mathrm{ng} \mathrm{m}^{-3}$. Although the technique does not provide speciation information, its strengths are its sensitivity and high time resolution, both of which are limitations of traditional filter-based methods. Our previous work has shown that the method is sensitive only to PAHs on the surfaces of particles and not those buried under other aerosol components (Marr et al., 2006), so measurements reported by the PAS are henceforth referred to as surface PAHs (SPAHs). In the Results section, we describe an approach for identifying measurements from the PAS that are not confounded by coating of the particles.

Aerosol active surface area, or Fuchs surface, is defined as that which is accessible to a molecule that might diffuse to a particle's surface. It was measured by diffusion charging (EcoChem DC $2000 \mathrm{CE}$ ). The DC analyzer generates a corona discharge which produces a cascade of electrons and ions that can attach to particles. As with the photoemission aerosol sensor for PAHs, a sensitive electrometer is then used to measure the current generated by the flow of charged particles. The analyzer reports active surface area of particles smaller than $\sim 100 \mathrm{~nm}$ at 10 -s resolution with a detection limit of $1 \mathrm{~mm}^{2} \mathrm{~m}^{-3}$. The simultaneous measurement of particle surface properties with the PAS and DC sensors 
Table 1. Mobile-laboratory-based SPAH statistics at different sites.

\begin{tabular}{lcc}
\hline Site (Dates in March) & \multicolumn{2}{c}{ SPAH $\left(\mathrm{ng} \mathrm{m}^{-3}\right)$} \\
\hline & Average $^{\mathrm{a}}$ & Maximum $^{\mathrm{b}}$ \\
Pedregal (4th-6th) & $7 \pm 16$ & 143 \\
Pico Tres Padres (7th-19th) & $2 \pm 2$ & 18 \\
T1 (19th-22nd) & $20 \pm 33$ & 229 \\
Santa Ana (22nd-25th) & $4 \pm 4$ & 29 \\
PEMEX (25th-27th) & $13 \pm 14$ & 80 \\
T0 (27th-31st) & $114 \pm 121$ & 604 \\
\hline
\end{tabular}

\footnotetext{
a Mean \pm one standard deviation of 1-min concentrations.

${ }^{\mathrm{b}}$ Maximum of 1-min concentrations.
}

has been described as a technique for fingerprinting different types of combustion particles (Bukowiecki et al., 2002).

All the PAH and AS analyzers were factory calibrated three months prior to the field campaign. At the beginning of the field campaign, we co-located and cross-calibrated the instruments against each other while measuring ambient air in Mexico City and then applied the resulting correction factors to all data. To facilitate analysis using diagnostic ratios and multivariate statistics, we averaged all data over a common 2- or 10-min interval. Effective black carbon (BC), operationally defined as the light-absorbing component of particles, was measured at 2-min intervals using an aethalometer (Magee Scientific AE-3) at a wavelength of $880 \mathrm{~nm}$.

\subsection{Measurement sites}

During the month-long MCMA field campaign in March 2006, we conducted measurements at the Instituto Mexicano del Petróleo (T0 supersite) and on board the Aerodyne Mobile Laboratory (AML), which visited six sites including the T0 supersite (Fig. 1). The supersite is located $10 \mathrm{~km}$ north of downtown Mexico City in the midst of a residential, commercial, and services area. It is surrounded by streets that are heavily traveled by light-duty vehicles and modern heavyduty diesel buses. The PAH and AS analyzers were situated on a building rooftop, approximately $15 \mathrm{~m}$ above ground level. The nearest major roads were $40 \mathrm{~m}$ away. To fulfill the objective of observing aged plumes, we selected the location and timing of the AML visits (Table 1) on the basis of meteorological analyses that identified sites that were generally downwind of the urban plume on certain days (de Foy et al., 2008).

The AML was designed and built by Aerodyne Research Inc. (Kolb et al., 2004). It was equipped with a comprehensive suite of gas and particle analyzers that measure carbon monoxide $(\mathrm{CO})$, carbon dioxide $\left(\mathrm{CO}_{2}\right)$, nitric oxide $(\mathrm{NO})$, nitrogen dioxide $\left(\mathrm{NO}_{2}\right)$, total nitrogen oxides $\left(\mathrm{NO}_{\mathrm{y}}\right)$, speciated volatile organic compounds (VOCs), SPAHs, AS, and $\mathrm{BC}$, among others. The AML's PAH analyzer was identical to that used at T0. BC was measured using a Multi An-

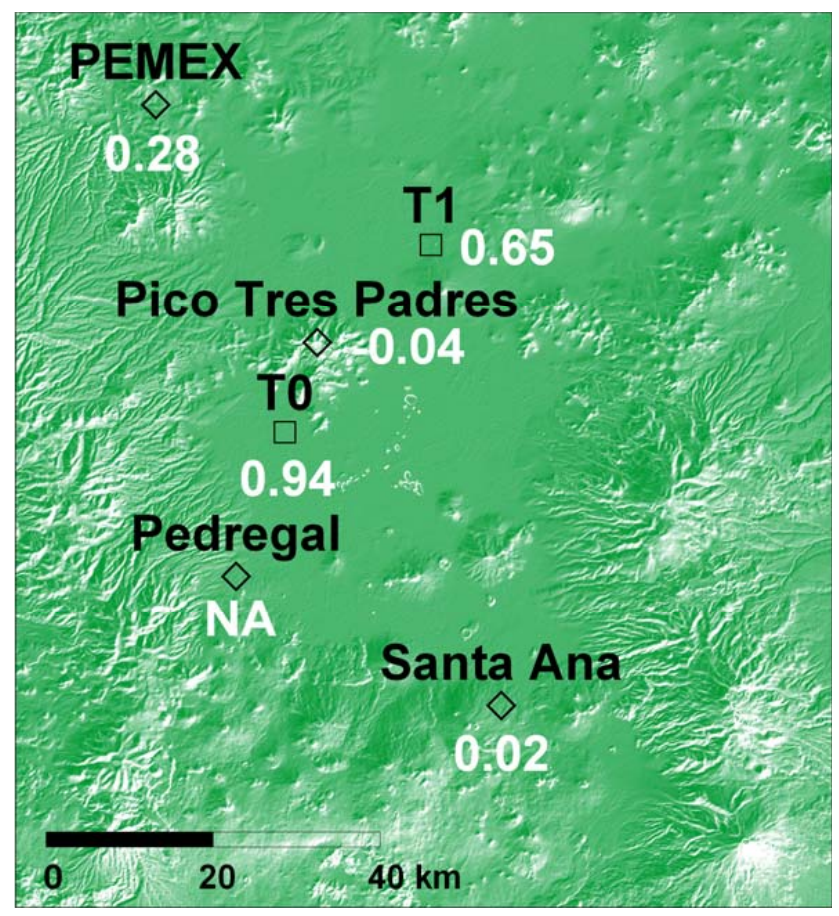

Fig. 1. Supersites (squares) and mobile laboratory measurement sites (diamonds) in the MCMA during the MILAGRO field campaign. The numbers in white are the linear correlation coefficients between SPAH measurements by the mobile laboratory and continuous measurements at $\mathrm{T} 0$.

gle Absorption Photometer (Thermo Electron Model 5012). During the field campaign, the AML drove to six sites and remained parked for 2-12 days at each location (Table 1). These sites encompassed varying environments, including residential, commercial, industrial, undeveloped, and mixed land use areas.

The AML visited the T0 and T1 supersites, Pedregal, Pico Tres Padres, Santa Ana, and PEMEX (Fig. 1). Intended to represent a mixture of fresh emissions and the partially aged Mexico City plume as it drifts downwind under certain meteorological conditions, the T1 supersite is located at the Universidad Technológica de Tecámac $\sim 30 \mathrm{~km}$ northeast of T0. Tecámac is a suburb in the State of Mexico and has a mixture of commercial and residential areas. The supersite is within $2 \mathrm{~km}$ of the town center, and the nearest road is several hundred meters away. Pedregal is located $\sim 25 \mathrm{~km}$ southwest of downtown Mexico City in a suburban residential area whose roads are lightly traveled. The sampling site was the JFK Elementary School, which is also one of the routine air quality monitoring sites for the environmental agency of the Mexico City Federal District Government. Pico Tres Padres, the site of the main television transmitters for the MCMA, is an isolated mountain $\sim 15 \mathrm{~km}$ north-northeast of T0 and $3000 \mathrm{~m}$ above sea-level, or $\sim 800 \mathrm{~m}$ above the valley floor. A single, mostly unused road runs up the mountain, and the 

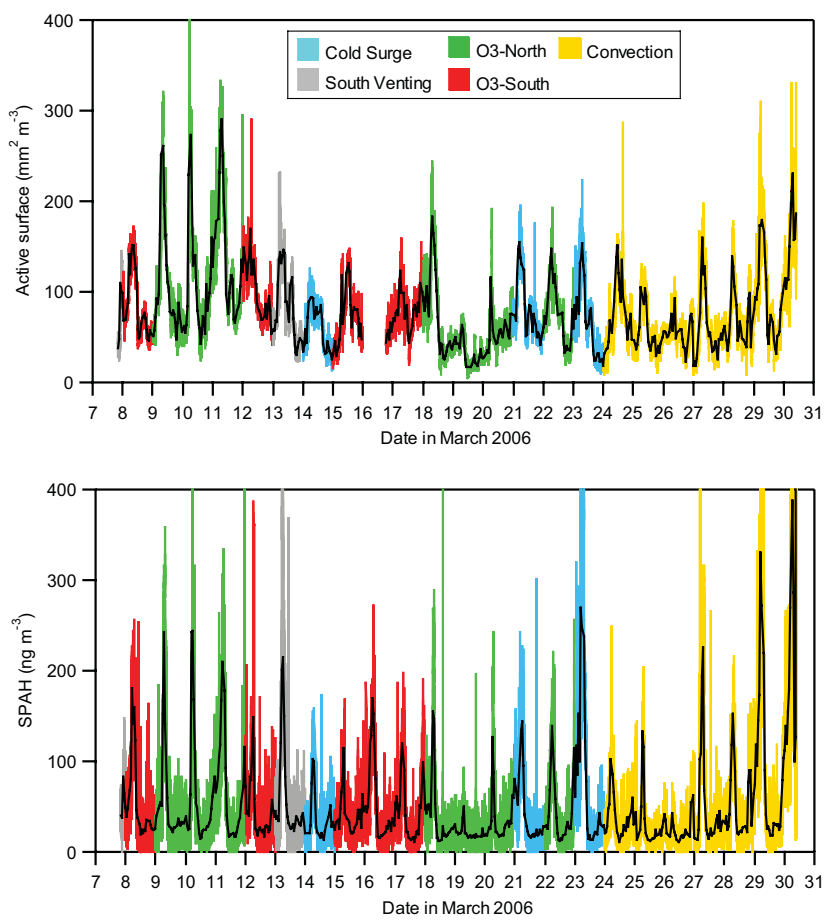

Fig. 2. AS and SPAH concentrations at TO during the entire field campaign. Raw 1-min measurements are shown by the colored lines, where color indicates the wind transport episode, and 1-h averages are shown in black.

surrounding area is not well traveled. Santa Ana is located in a rural area at the southern tip of the city, $\sim 40 \mathrm{~km}$ southeast of T0. Its roads are lightly traveled. Under certain meteorological conditions, Santa Ana represents an outflow receptor for air pollution coming from the city center. Located approximately $40 \mathrm{~km}$ north of the city, the PEMEX site is in a highly industrialized area closely situated to a major oil refinery ( $5 \mathrm{~km}$ away), cement plants, chemical factories, agricultural activities, and a power plant.

During the MCMA-2006 field campaign, air flow trajectories within the Mexico City basin and the fate of the urban plume were simulated, and five types of wind circulation patterns were identified (de Foy et al., 2005; de Foy et al., 2008): Cold Surge, South Venting, $\mathrm{O}_{3}-$ North, $\mathrm{O}_{3}$-South, and Convection (North and South). During the 31 days of the MCMA-2006 field campaign, three were Cold Surge (14, 21 , 23 March), eight were South Venting (1-7, 13 March), five were $\mathrm{O}_{3}$-South $(8,12,15-17 \mathrm{March})$, seven were $\mathrm{O}_{3}$-North (9-11, 18-20, 22 March), and eight were Convection (2431 March). The prevailing meteorological conditions can strongly influence ambient pollutant concentrations for given emission levels and also determine the regional impacts of the urban plume (de Foy et al., 2006).

To evaluate transport to sites and identify source areas, we carried out residence time analysis and concentration field analysis (Ashbaugh et al., 1985; de Foy et al., 2007; Seibert et al., 1994). Residence time analysis, calculated by summing back trajectories over a grid, produces a time exposure image of the back trajectories for a site, i.e. where the wind was coming from, over multiple hours. Concentration field analysis is the product of residence time analysis and pollutant concentrations at the receptor site each hour. The resulting concentration fields indicate the source areas or transport paths associated with high pollutant levels at a receptor site.

\section{Results}

Figure 2 displays time series of AS and total particulate SPAH concentrations at the T0 supersite. The raw 1-min measurements are shown by colored lines, whose color indicates the wind transport episode defined for each day. The black lines represent $1-\mathrm{h}$ averages and are intended to highlight diurnal patterns in the measurements. The highest AS concentrations occurred on $\mathrm{O}_{3}$-North and Convection days, while the highest average SPAH concentrations occurred on Convection days, which are defined by weak winds aloft (de Foy et al., 2008).

Strong diurnal patterns are evident in both AS and SPAHs. AS concentrations at T0 averaged $80 \mathrm{~mm}^{2} \mathrm{~m}^{-3}$ during the campaign, with a maximum 10 -s value of $760 \mathrm{~mm}^{2} \mathrm{~m}^{-3}$ on 30 March at 09:58. Typically, concentrations rose above $100 \mathrm{~mm}^{2} \mathrm{~m}^{-3}$ between 06:30-08:30 and then decreased throughout the remainder of the morning and afternoon to $\sim 50 \mathrm{~mm}^{2} \mathrm{~m}^{-3}$. SPAH concentrations averaged $50 \mathrm{ng} \mathrm{m}^{-3}$ throughout the campaign with a maximum value of $3660 \mathrm{ng} \mathrm{m}^{-3}$ on 30 March at 10:02, within minutes of the maximum AS observation. During the morning rush hour, SPAH concentrations generally rose to a maximum of $\sim 250 \mathrm{ng} \mathrm{m}^{-3}$ between 06:30-08:30 and then decreased throughout the remainder of the morning and afternoon to $\sim 20 \mathrm{ng} \mathrm{m}^{-3}$. The daily minima in AS were more variable than in SPAHs. Overnight concentrations rose as high as $75 \mathrm{ng} \mathrm{m}^{3}$. The daily maxima were nearly twice as high as observed at a site $17 \mathrm{~km}$ to the southeast in 2003 (Marr et al., 2006) and 1.5 times as high as observed at a site $13 \mathrm{~km}$ to the southwest in 2003 and 2005 (Baumgardner et al., 2007). In all three studies, the SPAH concentration measured by aerosol photoionization falls off more rapidly between 08:00-10:00 than do concentrations of other primary pollutants.

Table 1 summarizes SPAH concentrations at each site visited by the AML in chronological order. The highest average SPAH concentration was observed at T0 and the lowest at Pico Tres Padres and Santa Ana, the mountaintop and southern outflow sites, respectively. The maximum SPAH concentration occurred at T0. Figure 3 shows SPAH time series at each site. At Pedregal, SPAH concentrations were highest between 06:00-08:00 on Monday 6 March. They were slightly elevated in the hours before midnight on the evening of Saturday 4 March. These periods probably correspond 

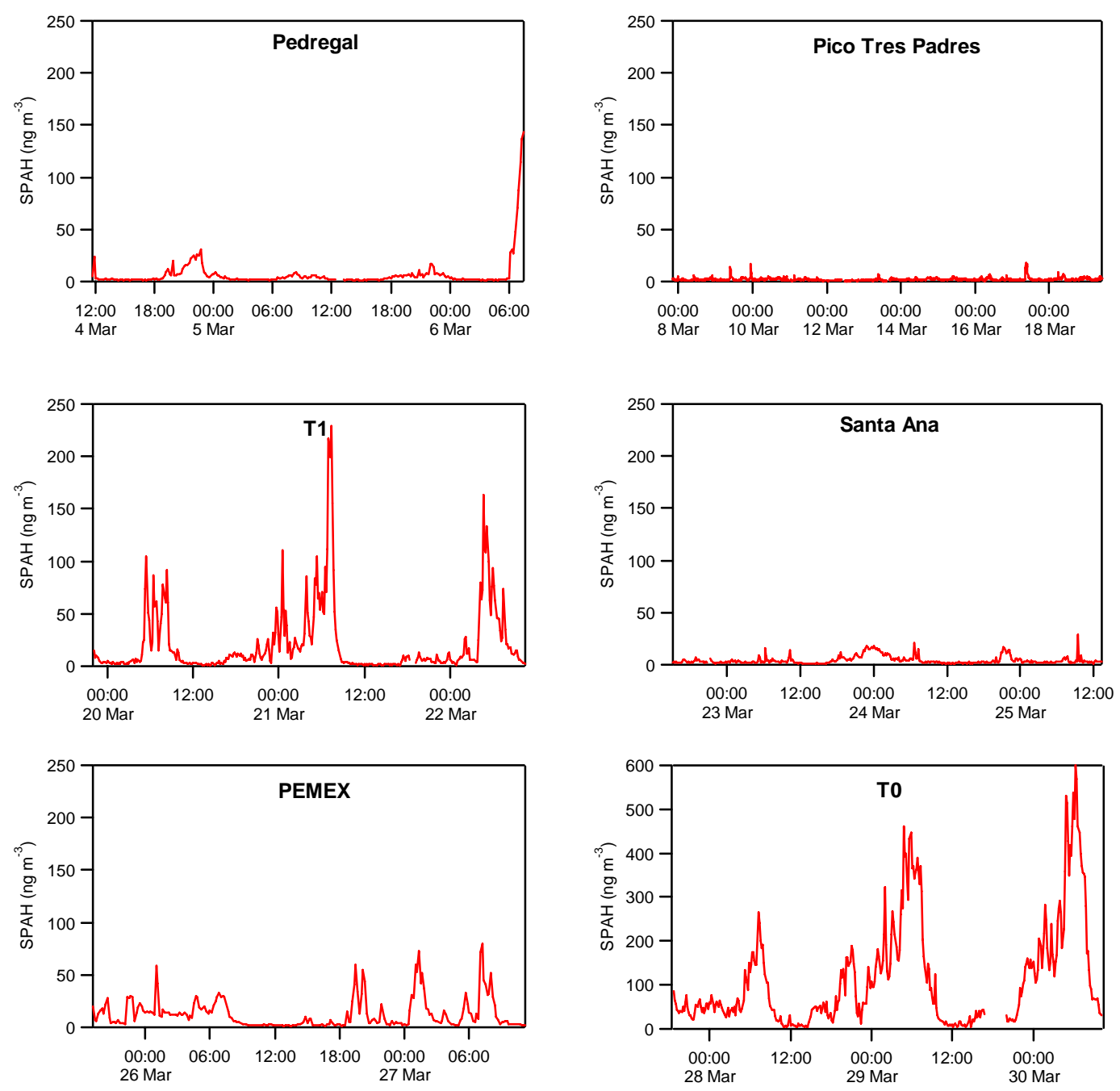

Fig. 3. SPAH concentrations (10-min averages) at sites visited by the AML. The y-axis maximum is larger in the T0 panel.

to the times of heaviest traffic and lowest boundary layer height. At Pico Tres Padres, SPAH concentrations remained below $10 \mathrm{ng} \mathrm{m}^{-3}$, even though fine particulate mass concentrations $\left(\mathrm{PM}_{2.5}\right)$, not shown, routinely rose at approximately 10:00 each day, as the boundary layer lifted up past the site. At T1, SPAH concentrations increased to $100-200 \mathrm{ng} \mathrm{m}^{-3}$ in the morning hours, well before 06:00.

Santa Ana lies at the southern edge of the basin, and here SPAH concentrations were always less than $30 \mathrm{ng} \mathrm{m}^{-3}$. Cold Surge conditions, in which the wind flushes from the center of the basin toward the south and past the site late into the evening (de Foy et al., 2008), prevailed on 23 March and may have contributed to the increase in SPAH concentrations centered around midnight of the 24th. At PEMEX, concentrations did not exceed $80 \mathrm{ng} \mathrm{m}^{-3}$ and the temporal patterns were irregular. The AML's observation period at T0 coincided with the highest observed concentrations of the field campaign.
The simultaneous measurement of SPAHs at T0 and other sites allows examination of their spatial variability in the MCMA. Figure 1 presents the Pearson correlation coefficients of 10-min SPAH concentrations at various sites visited by the AML against those measured continuously at the T0 supersite during periods of simultaneous measurements. A correlation factor could not be calculated for Pedregal because monitoring at $\mathrm{T} 0$ had not yet begun. Of course, the correlation was strongest when the AML was parked at T0. It was moderate at $\mathrm{T} 1$ and poor at all other sites. Correlations of BC between $\mathrm{T} 0$ and other sites were similar: -0.01 at Pico Tres Padres, 0.70 at T1, -0.06 at Santa Ana, 0.31 at PEMEX, and 0.95 at T0.

Next, we examine transport within the basin. Figure 4 shows the residence time and $\mathrm{BC}$ concentration field analyses for T0 during 27-31 March, which were all Convection days, and T1 during 19-22 March, which were $\mathrm{O}_{3}$-North and Cold Surge days. We chose to use BC as a proxy for PAHs 


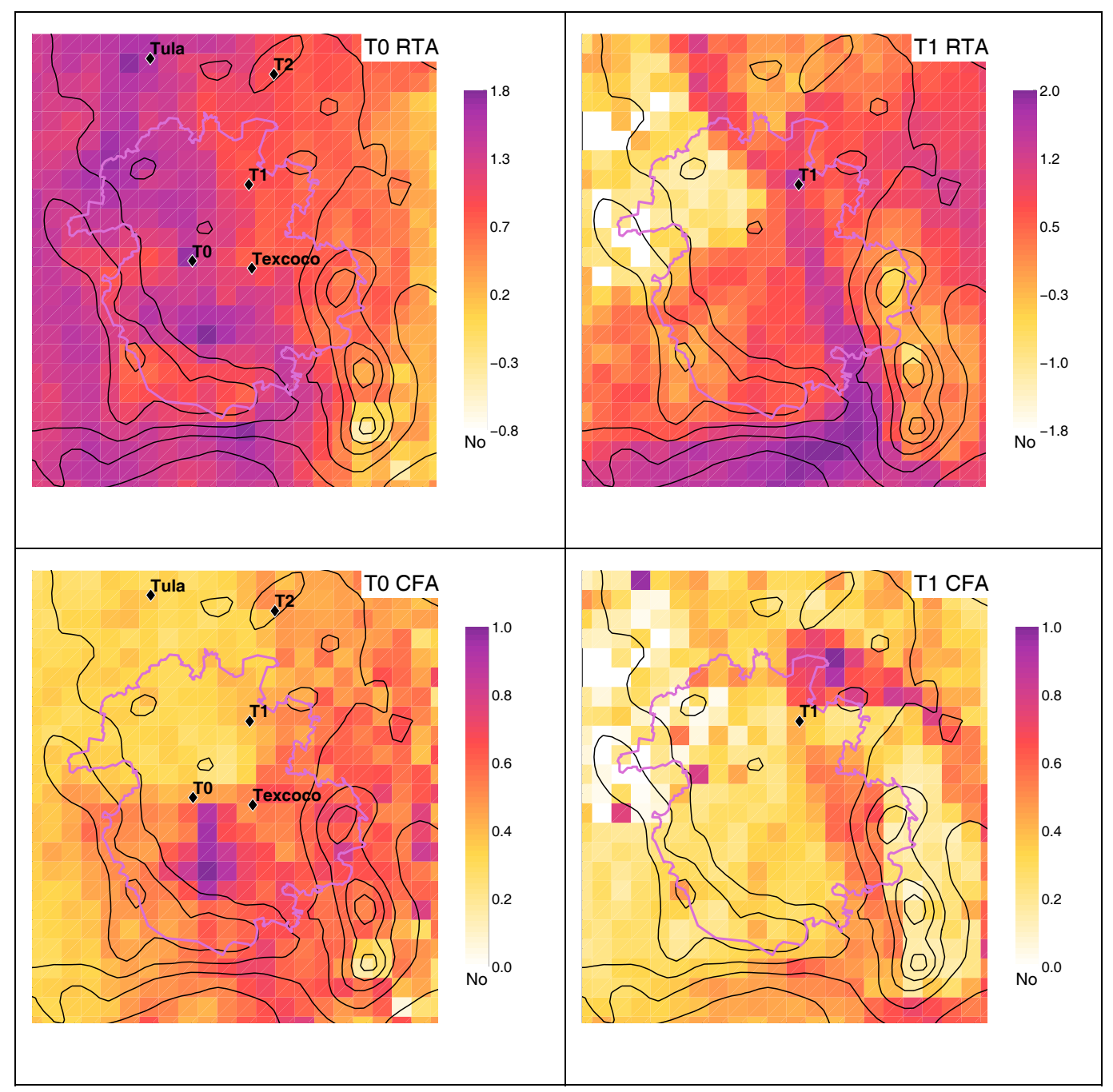

Fig. 4. Residence time (top) and BC concentration field (bottom) analyses at T0 on 27-31 March (left) and T1 on 19-22 March (right). Topography is indicated by black lines and the MCMA border by the pink line.

because SPAHs can be diminished by coating of the aerosol, as described later in the text. In the residence time analysis, the magnitude in each grid cell represents the probability of a back trajectory passing through the cell relative to the total time interval of the trajectory. In the concentration field analysis, areas with high values are the result of back trajectories associated with high concentrations at the receptor site, whereas low values result from back trajectories associated with low concentrations. For both analyses, the values are normalized, with the maximum color value corresponding to the 90th percentile for that grid. The residence time analyses are plotted on a log scale, as they decrease rapidly away from the receptor site; and the concentration field analyses are plotted on a linear scale.

While the residence time analysis shows that air parcels arriving at $\mathrm{T} 0$ are coming from all directions but less from the east, the concentration field analysis shows that high BC is associated with transport from the south, the center of the
MCMA. For T1, the residence time analysis shows three preferred directions: northwest, east and south (gap flow). However, the concentration field analysis shows that high BC is not associated with transport from the gap flow, but rather with transport from the northeast, where the highway to the MCMA is located. The gap flow is strong and clean. For Pedregal, PEMEX, and Santa Ana, the residence time analyses agree with the wind transport episodes on those days; and the concentration field analyses all show that high $\mathrm{BC}$ is associated with transport from the central urban area of the MCMA. The results for Pico Tres Padres-transport from all directions and high $\mathrm{BC}$ associated with the urban area-are more uncertain because of the challenges in obtaining accurate trajectories on this hilltop site.

The relationship between SPAHs and AS has been shown to be related to the source type and aging of the particles (Bukowiecki et al., 2002; Marr et al., 2004; Siegmann et al., 1999). Figure 5 illustrates the relationship between SPAH 

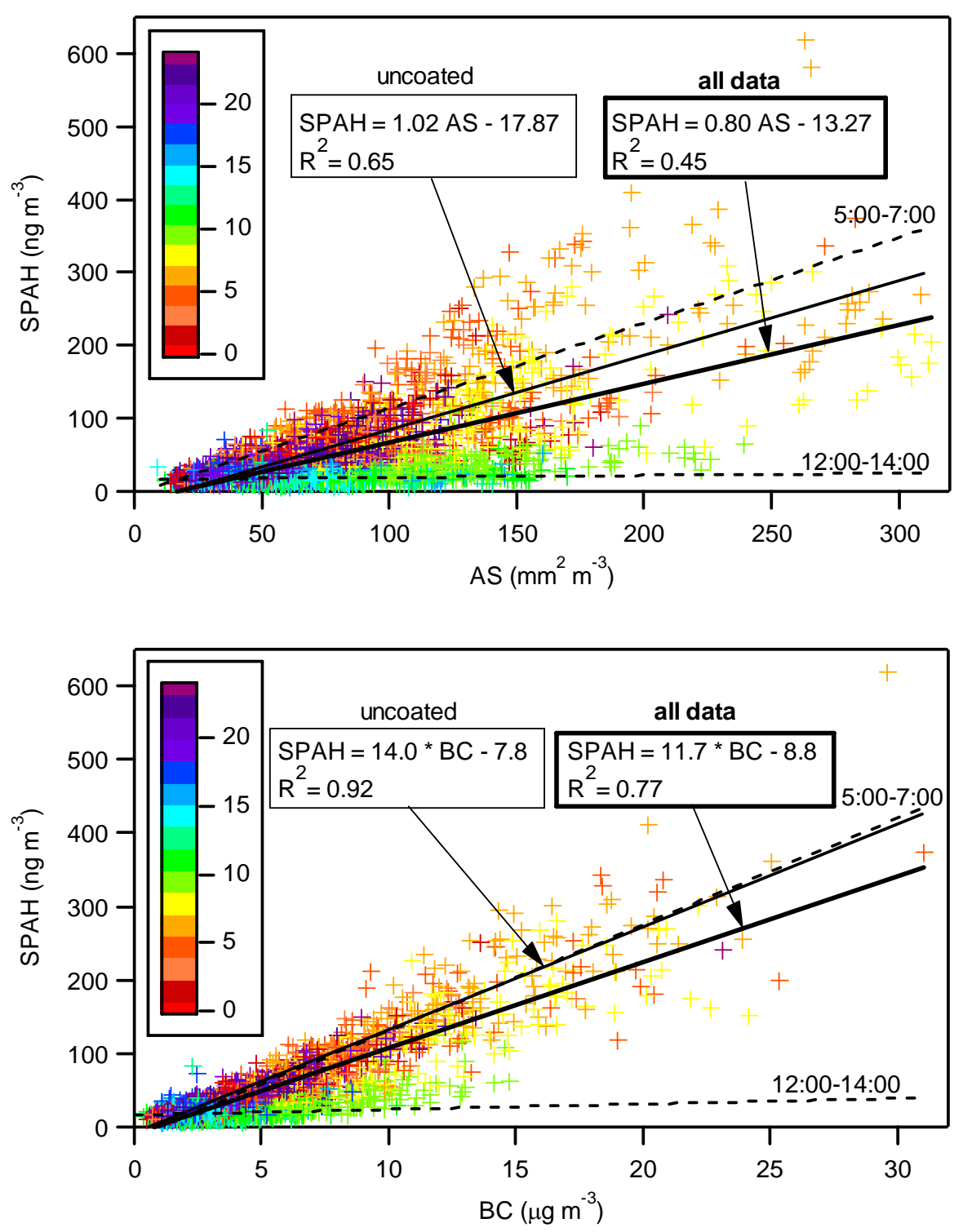

Fig. 5. SPAH v. AS and SPAH v. BC concentrations at T0 colored by hour. The dark solid line is the linear regression for all times, and the lighter solid line is the regression for uncoated particles. The dotted lines labeled 05:00-07:00 and 12:00-14:00 are the regressions for a subset of data specific to these time periods. The equations of these lines are given in the text.

and AS (10-min averages) at T0. The color indicates the time of day of each measurement. There is considerable scatter in the data; the correlation involving all data is fair, with $R^{2}=0.45$. For the subset of data between 05:00-07:00, just before sunrise, the equation of the line is SPAH $=1.17 \times \mathrm{AS}-$ 3.20 with $R^{2}=0.58$. For the subset of data between $12: 00$ $14: 00$, the equation of the line is $\mathrm{SPAH}=0.03 \times \mathrm{AS}+16.33$ with $R^{2}=0.01$. Figure 5 shows that higher SPAH/AS ratios, i.e. those points falling above the regression line, and those with high absolute SPAH and AS values, tend to occur during the early morning hours. The slope of the regression line is 39 times higher in the morning compared to the afternoon. The regression line for the subset of data representing par- ticles that have not been coated by secondary aerosol (described below) falls between the lines for all data and the subset between 05:00-07:00; of the four lines shown, it has the highest $R^{2}$. There is no clear relationship between the ratio and wind transport episode.

Figure 5 also shows SPAHs versus BC at T0, classified by time of day. PAHs and $\mathrm{BC}$ are expected to be correlated since both originate from combustion sources. For all times, the correlation between SPAHs and BC is stronger $\left(R^{2}=0.77\right)$ than between SPAHs and AS, and the slope of the line, $11.7 \pm 0.1 \mathrm{ng} \mathrm{g}^{-1}$, indicates that SPAHs are $1 \%$ of BC by mass. As with SPAH/AS, higher SPAH/BC ratios tend to occur during the morning rush hour period. 


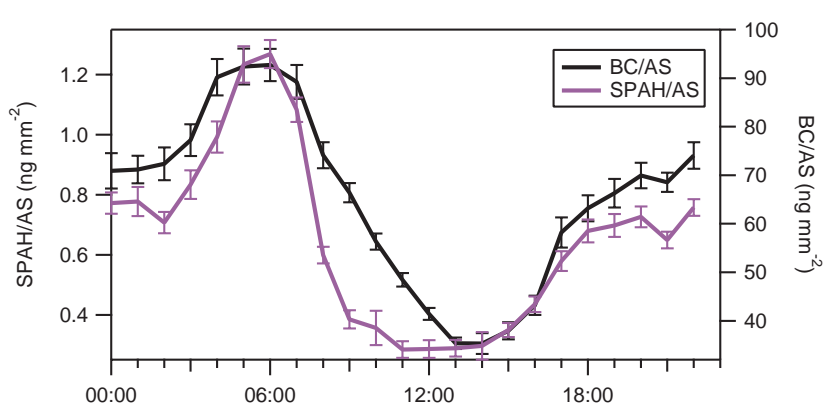

Fig. 6. Weekday average diurnal patterns in SPAH/AS and BC/AS.

As the day progresses, SPAH/BC ratios tend to decrease and are lowest between 12:00-18:00. The equation of the regression line between 05:00-07:00 is $\mathrm{SPAH}=14.4 \times \mathrm{BC}-$ 13.8 with $R^{2}=0.82$, where SPAH is in $\mathrm{ng} \mathrm{m}^{-3}$ and $\mathrm{BC}$ is in $\mu \mathrm{g} \mathrm{m}^{-3}$. Later in the afternoon, between 12:00-14:00, the relationship is $\mathrm{SPAH}=0.76 \times \mathrm{BC}+16.2$ with $R^{2}=0.02$. The slope is 19 times higher in the morning. The regression line for the subset of data representing particles that have not been coated by secondary aerosol is similar to that for the hours of 05:00-07:00; of the four lines shown, it has the highest $R^{2}$.

Figure 6 shows average weekday diurnal patterns of the ratios SPAH/AS and BC/AS. The latter is an indicator of the fraction of particles that are of combustion origin at any time (Burtscher et al., 1993), as BC is expected to be minimally reactive. The BC/AS ratio peaks around the morning rush hour and then falls off steadily throughout the late morning and early afternoon. During this period, growth of secondary aerosol in Mexico City is considerable (Molina et al., 2007; Salcedo et al., 2006; Volkamer et al., 2006) and contributes to AS but not BC. Even though both PAHs and BC are of combustion origin, their ratios to AS diverge between 07:0012:00, with SPAH/AS falling off more rapidly than BC/AS. This observation is probably due to physical coating of the particles by secondary aerosol, which shields the PAHs from detection by the photoemission method (Marr et al., 2006).

Pollutant ratios can provide insight into sources of emissions, chemical transformations, and spatial and temporal variability in concentrations. Because of the measurement artifact associated with the photoemission method, i.e. that it does not detect PAHs that are buried under other aerosol components, we must screen out such measurements when calculating ratios. To do so, we assume that the ratio of total PAHs to BC should be approximately constant. Based on the regression results shown in Fig. 5, we examine the time series of $(\mathrm{SPAH}+10) / \mathrm{BC}$, with SPAH in $\mathrm{ng} \mathrm{m}^{-3}$ and $\mathrm{BC}$ in $\mu \mathrm{g} \mathrm{m}^{-3}$. Excluding the period corresponding to the most active photochemistry between 08:00-13:00 when primary combustion particles are most likely to be coated by secondary aerosol, the diurnal average is $13.6 \pm 0.6 \mathrm{ng} \mu \mathrm{g}^{-1}$. The coefficient of variation is only $4.4 \%$. Between 08:0013:00, the value is significantly lower, ranging from 7.2 to $10.2 \mathrm{ng} \mu \mathrm{g}^{-1}$. We therefore apply the criterion $(\mathrm{SPAH}+10)$
/ $\mathrm{BC}>11 \mathrm{ng} \mu \mathrm{g}^{-1}$ to identify data points representing uncoated particles.

Table 2 shows the slope and standard error of the leastsquares linear regression and correlation coefficient $\left(R^{2}\right)$ between SPAHs and carbon monoxide (CO), total nitrogen oxides $\left(\mathrm{NO}_{\mathrm{y}}\right)$, carbon dioxide $\left(\mathrm{CO}_{2}\right)$, and $\mathrm{BC}$ measured by the AML. The table presents results calculated using all SPAH data and only uncoated SPAH data, screened using the criterion previously described. In most cases, except for Pico Tres Padres, focusing on fresh SPAH produces higher slopes and stronger correlations. Measurements at Pedregal took place over a weekend, so results from this site may not be representative.

At the remaining sites (T1, Santa Ana, PEMEX, and T0), the strongest correlations and highest slopes tend to be observed at the more urbanized locations, T0 and T1. The different slopes are likely to be indicative of a different mix of sources at each site. Fresh SPAHs are reasonably well correlated with CO, with an $R^{2}$ of 0.72 to 0.93 . The SPAH/CO slope is similar at T1, PEMEX, and T0 and an order of magnitude lower at Santa Ana. Fresh SPAHs are even more strongly correlated with $\mathrm{NO}_{\mathrm{y}} ; R^{2}$ values range from 0.86 to 0.96 at the last four sites shown in Table 2. The SPAH/NO and $\mathrm{SPAH} / \mathrm{CO}_{2}$ slopes are highest at $\mathrm{T} 1$ and $\mathrm{T} 0$, moderate at PEMEX, and lowest at Santa Ana. The regressions between SPAHs and true $\mathrm{NO}_{\mathrm{x}}$ are not significantly different from those with $\mathrm{NO}_{\mathrm{y}}$, so henceforth, we will refer to the relationship as with $\mathrm{NO}_{\mathrm{x}}$. This notation will facilitate comparison with other studies, the majority of which use chemiluminescence and report results as $\mathrm{NO}_{\mathrm{x}}$. When all data are consid-

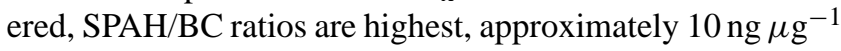
at Pedregal, T1, and T0; and the correlations are strongest at these three sites and PEMEX. The correlations improve considerably for uncoated particles.

Table 3 contrasts SPAH/BC ratios at T0 in Mexico City with those measured in three other cities, where the same aerosol photoionization method was used to measure SPAHs. The mass ratio of SPAHs to BC in Mexico City is similar to that measured along a freeway loop in the Los Angeles area and approximately 8-30 times higher than in diluted vehicle exhaust in Ogden, Utah and ambient air in Fresno, California. The correlation factors between SPAHs and BC are similar in all cities. Limiting the analysis to uncoated PAHs in Mexico City does not have a large effect on the ratio.

\section{Discussion}

\subsection{PAH and AS concentrations, sources, and aging}

PAH concentrations may vary considerably between cities due to differences in emission sources and meteorological conditions. Mexico City's SPAH concentrations, a lower limit of total particulate PAHs, are substantially higher than those measured in other large cities. Eiguren-Fernandez 
Table 2. Least-squares linear regression slope \pm standard error and $R^{2}$ between SPAHs and gaseous pollutants for all SPAH data (top set of numbers) and uncoated particles only (bottom set of numbers).

\begin{tabular}{|c|c|c|c|c|c|c|c|c|}
\hline Site & $\begin{array}{l}\text { SPAH/CO slope } \\
\left(\mathrm{ng} \mathrm{m}^{-3} \mathrm{ppb}^{-1}\right)\end{array}$ & $R^{2}$ & $\begin{array}{l}\mathrm{SPAH} / \mathrm{NO}_{\mathrm{y}}^{\mathrm{a}} \text { slope } \\
\left(\mathrm{ng} \mathrm{m}^{-3} \mathrm{ppb}^{-1}\right)\end{array}$ & $R^{2}$ & $\begin{array}{l}\mathrm{SPAH} / \mathrm{CO}_{2} \text { slope } \\
\left(\mathrm{ng} \mathrm{m}^{-3} \mathrm{ppm}^{-1}\right)\end{array}$ & $R^{2}$ & $\begin{array}{l}\text { SPAH/BC slope } \\
\quad\left(\mathrm{ng} \mu \mathrm{g}^{-3}\right)\end{array}$ & $R^{2}$ \\
\hline \multirow[t]{2}{*}{ Pedregal } & $0.0208 \pm 0.0009$ & 0.69 & $0.12 \pm 0.02$ & 0.18 & $0.61 \pm 0.04$ & 0.51 & $10.4 \pm 0.5$ & 0.59 \\
\hline & $0.0285 \pm 0.0005$ & 0.98 & $0.2 \pm 0.1$ & 0.15 & $0.94 \pm 0.04$ & 0.88 & $15.7 \pm 0.3$ & 0.09 \\
\hline \multirow[t]{2}{*}{ Pico Tres Padres } & $0.0027 \pm 0.0002$ & 0.17 & $0.060 \pm 0.002$ & 0.26 & $0.121 \pm 0.007$ & 0.16 & $0.077 \pm 0.008$ & 0.06 \\
\hline & $0.003 \pm 0.007$ & 0.04 & $0.04 \pm 0.01$ & 0.03 & $0.03 \pm 0.01$ & 0.02 & $0.6 \pm 0.1$ & 0.04 \\
\hline \multirow[t]{2}{*}{$\mathrm{T} 1$} & $0.090 \pm 0.003$ & 0.77 & $1.10 \pm 0.02$ & 0.87 & $1.4 \pm 0.2$ & 0.38 & $10.0 \pm 0.2$ & 0.88 \\
\hline & $0.087 \pm 0.005$ & 0.93 & $1.20 \pm 0.04$ & 0.96 & $4 \pm 2$ & 0.72 & $11.32 \pm 0.09$ & 1.00 \\
\hline \multirow[t]{2}{*}{ Santa Ana } & $0.0122 \pm 0.0007$ & 0.44 & $0.22 \pm 0.02$ & 0.34 & $0.29 \pm 0.02$ & 0.33 & $1.8 \pm 0.2$ & 0.17 \\
\hline & $0.0171 \pm 0.0007$ & 0.80 & $0.34 \pm 0.01$ & 0.86 & $0.46 \pm 0.02$ & 0.68 & $8.7 \pm 0.3$ & 0.87 \\
\hline \multirow[t]{2}{*}{ PEMEX } & $0.047 \pm 0.004$ & 0.34 & $0.62 \pm 0.02$ & 0.86 & $1.1 \pm 0.1$ & 0.37 & $6.5 \pm 0.2$ & 0.77 \\
\hline & $0.13 \pm 0.01$ & 0.75 & $0.79 \pm 0.02$ & 0.95 & $3.1 \pm 0.2$ & 0.87 & $11.2 \pm 0.3$ & 0.96 \\
\hline \multirow[t]{2}{*}{ T0 } & $0.066 \pm 0.004$ & 0.47 & $1.19 \pm 0.03$ & 0.77 & $3.3 \pm 0.1$ & 0.70 & $10.0 \pm 0.2$ & 0.85 \\
\hline & $0.096 \pm 0.005$ & 0.72 & $1.45 \pm 0.03$ & 0.95 & $4.3 \pm 0.1$ & 0.87 & $11.5 \pm 0.2$ & 0.97 \\
\hline
\end{tabular}

${ }^{a} \mathrm{NO}_{\mathrm{y}}$ is total nitrogen oxides measured by chemiluminescence with a molybdenum converter. The ratios are not significantly different when true $\mathrm{NO}_{\mathrm{x}}=\mathrm{NO}+\mathrm{NO}_{2}$ is used instead.

et al. (2004) measured total particulate PAH concentrations of $0.5 \mathrm{ng} \mathrm{m}^{-3}$ and $2 \mathrm{ng} \mathrm{m}^{-3}$ in rural and urban areas of Los Angeles, respectively. In contrast, concentrations in rural and urban areas of Mexico City are nearly 25 times higher. In Hong Kong, particulate PAH concentrations ranged from $0.41 \mathrm{ng} \mathrm{m}^{-3}$ to $48 \mathrm{ng} \mathrm{m}^{-3}$ in rural to urban areas (Zheng and Fang, 2000). These values compare more closely with Mexico City; however, PAH concentrations in Mexico City are still higher. PAHs have also been measured in different environments of Greece (Mantis et al., 2005), where total particulate concentrations ranged from $2 \mathrm{ng} \mathrm{m}^{-3}$ to $52 \mathrm{ng} \mathrm{m}^{-3}$ in rural to urban areas. Again, these values compare more closely with the results seen in Mexico City, but the values for Mexico City are higher yet.

The database of measurements of ambient AS in other cities is considerably smaller. Mexico City's mean AS concentration of $80 \mathrm{~mm}^{2} \mathrm{~m}^{-3}$ at T0 is comparable to that found in Los Angeles, where mean concentrations of 69 and $53 \mathrm{~mm}^{2} \mathrm{~m}^{-3}$ were recorded at two ambient locations (Ntziachristos et al., 2007). AS in a residential area of Redwood City ranged between $40-300 \mathrm{~mm}^{2} \mathrm{~m}^{-3}$, with the higher concentrations attributed to wood burning and fireplaces in the neighborhood (Ott and Siegmann, 2006). It appears that while particulate PAH loading in Mexico City is higher than in many other cities, its aerosol surface area loading is not comparatively extraordinary.

Vehicular traffic has been recognized as the major contributor to PAH emissions in urban areas (Kittleson et al., 2004; Lee et al., 1995), and therefore it is not surprising that the highest average SPAH and AS concentrations are found at T0, where traffic is heaviest. The timing of SPAH and AS peaks at the more urban locations corresponds to periods of rush hour traffic. Burtscher et al. (1993) also found the high-
Table 3. Total particulate SPAH/BC mass ratios in Mexico City compared to other locations.

\begin{tabular}{llll}
\hline Location & $\begin{array}{l}\text { SPAH/BC } \\
\text { (mass ratio) }\end{array}$ & $R^{2}$ & Reference \\
\hline Mexico City (T0) & & & \\
$\quad$ All data & $1.2 \times 10^{-2}$ & 0.77 & This study \\
$\quad$ Uncoated SPAH & $1.4 \times 10^{-2}$ & 0.93 & This study \\
Ogden, UT & $1.25 \times 10^{-3}$ & 0.75 & (Arnott et al., 2005) \\
Fresno, CA (Winter) & $1.2 \times 10^{-3}$ & 0.78 & (Arnott et al., 2005) \\
Fresno, CA (Summer) & $3.3 \times 10^{-4}$ & 0.75 & (Arnott et al., 2005) \\
Los Angeles, CA & $1 \times 10^{-2}$ & 0.82 & (Westerdahl et al., 2005) \\
\hline
\end{tabular}

${ }^{a}$ Diluted vehicle exhaust, not ambient air.

est PAH and AS values in Zurich to occur during rush hour and ascribed them to motor vehicles.

At some locations, including Pedregal, T1, and PEMEX, increases in SPAH concentrations occur at nighttime between 23:00 and 04:00 (Fig. 3). The increase in SPAHs may be due to transport of particles emitted earlier in the evening during times of high traffic density, or it may indicate the presence of other nighttime sources. Speciation measurements in 2003 suggest that wood and trash burning contribute to PAHs observed at night (Marr et al., 2006). The impact of emissions at nighttime can be magnified because of stable atmospheric conditions. Some industries are thought to switch to using dirtier fuels and processes at night, when enforcement of regulations is less likely. Furthermore, at T1 during the first two weeks of the field campaign, Doran et al. (2007) observed increased organic and elemental carbon during nighttime hours with peak values attained in the morning hours near sunrise. 
A similar pattern occurred at T1 on 21 March. The temporal variations imply that at night a buildup of pollution from nearby urban sources is occurring, followed by a subsequent dilution during the next morning as the boundary layer expands.

Spatial and temporal patterns in concentrations indicate not only potential sources of PAHs but also the degree of atmospheric processing the particles undergo. As emissions are transported, they are subject to dilution and other transformations. This behavior is supported by Fig. 3, which shows that in general, higher SPAH concentrations occur at $\mathrm{T} 0$ and PEMEX, which are dominated by fresh emissions. Lower concentrations occur at Pico Tres Padres and Santa Ana, which are receptor sites where emissions have undergone dilution and aging by the time they arrive. Intermediate concentrations occur at $\mathrm{T} 1$ and Pedregal, which lie between the two extremes.

SPAHs as detected by the surface-specific photoemission method may diminish due to coating by secondary aerosol, and Figs. 4 and 5 support this hypothesis. PAH loss by photodegradation, heterogeneous reactions, or volatilization is less likely because measurements in 2003 showed that even when surface-bound PAHs diminish, PAHs are still detected by aerosol mass spectrometry, a method that is able to detect them anywhere in the particles, not just on the surface (Marr et al., 2006). An increase in secondary aerosol in the mid-morning hours contributes to aerosol surface area and is expected to cause a reduction in both SPAH/AS and BC/AS ratios, but it does not explain the decrease in SPAH/BC ratio (Fig. 5) or the divergence between the two (Fig. 6). Studies using a variety of techniques have shown that primary combustion particles are rapidly coated by secondary aerosol within a few hours in Mexico City (Baumgardner et al., 2007; Dzepina et al., 2007; Johnson et al., 2005; Marr et al., 2006; Salcedo et al., 2006). This finding could explain the temporal patterns observed in SPAH/AS and SPAH/BC ratios because secondary aerosol formation would not increase the total mass of PAHs but could contribute to it being coated. After condensation of secondary aerosol on primary combustion particles, the PAHs on the surfaces of primary particles would no longer be detectable by the photoionization method, but BC would remain detectable by the light absorption method. In contrast, the ratios of SPAH/AS and SPAH/BC were found to be much more constant throughout the day at a port south of Los Angeles (Polidori et al., 2008). The difference may be due to the upwind location of this site, which experiences relatively clean inflow from the Pacific Ocean and thus less secondary aerosol formation.

Pico Tres Padres is of special interest because it sits $800 \mathrm{~m}$ above the valley floor, and during the morning hours, it is above the mixing (boundary) layer that contains freshly emitted pollutants. Its diurnal patterns of particulate mass loading differ from those at sites on the valley floor. $\mathrm{PM}_{2.5}$ concentrations increase around 10:00 each day, coinciding with the rising of the boundary layer, verified visually, up to the AML's location on the mountain. Particle surface PAH concentrations, however, do not rise concomitantly, further supporting the proposition that initially fresh combustion emissions from the valley below have undergone transformations that inhibit the detection of surface-bound PAHs.

The rapid coating of primary combustion particles in the megacity environment could have important implications for PAH longevity in the atmosphere. Experiments have shown that particulate PAHs can decay in the presence of sunlight (Kamens et al., 1988) and can undergo heterogeneous reactions with the hydroxyl radical, ozone, and $\mathrm{NO}_{\mathrm{x}}$ (Esteve et al., 2006; Kwamena et al., 2007; Molina et al., 2004). However, if the PAHs are coated by secondary aerosol, they may be less susceptible to degradation and may persist long enough to be transported to remote areas.

\subsection{Intersite correlations of SPAH and BC}

Figure 1 shows that SPAH intersite correlation coefficients calculated for other sites versus T0 are quite weak, except for T1. It is possible that the spatial correlations for aged PAHs might be stronger, but the intersite correlations for $\mathrm{BC}$, which serves as a proxy for total particulate PAHs, are similar to those for SPAH. While strong intersite correlations would indicate spatially uniform emission patterns and sources and regional-scale mixing of pollutants, the results for Mexico City suggest that PAHs vary considerably in space. Concentrations at individual sites are largely independent of one another and are instead dominated by local sources, and/or fresh combustion particles have been sufficiently transformed that surface-bound PAHs are no longer present by the time the particles reach other sites. This conclusion is further supported by the lack of a consistent relationship between SPAH and AS concentrations and wind transport episodes (Fig. 2); regional-scale meteorological patterns do not have a strong effect on concentrations.

Mantis et al. (2005) and Siegmann et al. (1999) report generally higher correlation coefficients for their intersite comparisons during studies of PAHs in Greece and Switzerland, respectively. The study in the Greater Athens area of Greece found an intersite correlation of $r=0.61$ between two urban locations, $r=0.76$ between an urban location and a background location, and $r=0.57$ between an urban location and a mixed-urban industrial location. An important implication for risk assessment studies is that a single monitoring site in Mexico City will not adequately represent the population's exposure.

\subsection{Correlation of SPAHs with AS, $\mathrm{NO}_{\mathrm{x}}, \mathrm{CO}_{2}, \mathrm{CO}$, and $\mathrm{BC}$}

The ratio of SPAH to AS concentrations has been described as a fingerprint for different types of combustion particles (Bukowiecki et al., 2002; Matter et al., 1999; Siegmann et al., 1999). The relationship between these parameters provides 
a qualitative means of identifying different sources and describing the physical and chemical properties of particles. In contrast to previous studies which have shown tighter relationships between SPAHs and AS for specific sources such as diesel exhaust, roadway vehicle emissions, candles, fires, and cigarettes (Bukowiecki et al., 2002; Marr et al., 2004; Siegmann et al., 1999), the relationship shown in Fig. 5 contains significantly more scatter. For a single source, the relationship between SPAHs and AS is expected to be linear with a characteristic slope. The spread of the data indicates that the aerosol represents a mixture of different sources and particles of different ages. Ambient measurements in complex environments are expected to produce such results.

The stronger correlation of SPAHs with $\mathrm{NO}_{\mathrm{x}}$ and $\mathrm{BC}$, versus with $\mathrm{CO}$ and $\mathrm{CO}_{2}$ (Table 2), likely reflects the importance of diesel engines as sources of both $\mathrm{PAH}$ and $\mathrm{NO}_{\mathrm{x}}$ emissions (Harley et al., 2005; Marr et al., 1999). CO is emitted mainly by gasoline-powered vehicles, which emit far lower particulate PAHs than do diesel engines (Marr et al., 2002). Weak positive correlations between $\mathrm{PAHs}$ and $\mathrm{NO}_{\mathrm{x}}$ have also been reported in Brisbane, Australia (Muller et al., 1998).

The ratios should be higher and correlations stronger in source areas and receptor sites with a large impact of local sources, and the results shown in Table 2 support this hypothesis. The highest ratios of SPAH to the four other pollutants and strongest correlations occur at T1 and T0. In MILAGRO, $\mathrm{T} 1$ is generally considered a receptor site, but concentration field analysis (Fig. 4) shows that it has strong local sources; and T0 is the closest site to the center of the MCMA. Values are intermediate at Pedregal and PEMEX, both of which are located toward the outskirts of the MCMA. Values are lowest at Pico Tres Padres and Santa Ana, the first of which can be thought of as a vertically downwind receptor site and the second of which is an outflow point of the MCMA basin.

Pollutant ratios can be useful for estimating emissions and for describing the evolution of source strengths over decadal time scales (Marr et al., 2002). The mass ratio of particulate SPAH/NO $\mathrm{NO}_{\mathrm{x}}$ measured along roads during the MCMA-2003 field campaign was $4.7 \pm 5.9 \times 10^{-4}$ (Jiang et al., 2005). During the MCMA-2006 field campaign, this ratio was $1.09 \pm 0.05 \mathrm{ng} \mathrm{m}^{-3} \mathrm{ppb}^{-1}$, or $7.7 \pm 0.4 \times 10^{-4}$ in mass terms, at T0 (and similar at the other urbanized sites T1 and PEMEX). The ratio in 2006 has not changed significantly from that measured in 2003, within the precision of the methods used.

While the mass ratio of SPAH/BC at T0 (Table 3) is similar to that observed along a freeway loop in the Los Angeles area (Westerdahl et al., 2005), lower ratios were found in ambient air in Fresno, California and diluted vehicle exhaust in Ogden, Utah (Arnott et al., 2005). The similarity in SPAH/BC between T0 and the Los Angeles freeway may indicate that vehicular sources are similar in the two locations and dominate measurements at T0 or alternatively, if particles have aged slightly by the time they reach the elevated T0 measurement site, may indicate that the SPAH/BC ratio in fresh emissions in Mexico City is actually higher than in Los Angeles. The ambient ratio in Mexico City is nearly 10 times higher than in Fresno. Direct measurements of exhaust are needed to determine whether particulate emissions from Mexico City's vehicles contain higher amounts of PAHs than in the U.S. If so, PAH emissions could be minimized by reducing the PAH content of fuels (Marr et al., 1999).

\section{Conclusions}

It is apparent that PAH pollution is a major problem in the more heavily trafficked areas of the MCMA. SPAH concentrations near downtown exhibit a consistent diurnal pattern and routinely exceed $200 \mathrm{ng} \mathrm{m}^{-3}$ during the morning rush hour. Weak correlations between SPAHs and AS are indicative of the wide variety of sources and ages of particles present in Mexico City. SPAH concentrations are poorly correlated in space, and therefore PAHs should not be treated as a regional-scale pollutant. An important implication of this result is that for risk assessment studies, a single monitoring site will not adequately represent an individual's exposure. The stronger correlation of SPAHs with $\mathrm{NO}_{\mathrm{x}}$, rather than with $\mathrm{CO}$ and $\mathrm{CO}_{2}$, probably reflects the importance of diesel engines as sources of both $\mathrm{PAH}$ and $\mathrm{NO}_{\mathrm{x}}$ emissions. Mexico City's SPAH/BC ratio is similar to that found along freeways in Los Angeles and 8-30 times higher than that found in two other cities. Aging of primary combustion particles by coating with secondary aerosol appears to result in a decrease in surface SPAH/AS and SPAH/BC ratios over the course of the day and may prolong the lifetime of PAHs in the atmosphere. The photoemission method used in this study to measure PAHs detects only those on particles' surfaces. This specificity can be considered a strength if PAHs' toxicity is mediated via interactions with only the outer surfaces of particles but a weakness if one is attempting to characterize total particulate PAH concentrations. Measurements using other techniques such as aerosol mass spectrometry may be more representative of the total, although photoemission is a more sensitive technique at present.

Acknowledgements. We thank C. Mazzoleni, E. Deustua, X. Yao, M. Cubison, and M. Alexander for their support; the managers of the supersites (T0 and T1) for the use of their facilities; and C. Kolb for the use of the Aerodyne Mobile Laboratory. Financial support was provided by the U.S. National Science Foundation (ATM-0528227) and the U.S. Department of Energy (DE-FG0205ER63980). This study was also supported by the Molina Center for Strategic Studies in Energy and the Environment. D. Thornhill is supported by a Fulbright Fellowship.

Edited by: S. Madronich 


\section{References}

Ashbaugh, L. L., Malm, W. C., and Sadeh, W. Z.: A residence time probability analysis of sulfur concentrations at Grand Canyon National Park, Atmos. Environ., 19, 1263-1270, 1985.

Arnott, W. P., Zielinska, B., Rogers, C. F., Sagebiel, J., Park, K. H., Chow, J., Moosmuller, H., Watson, J. G., Kelly, K., Wagner, D., Sarofim, A., Lighty, J., and Palmer, G.: Evaluation of 1047$\mathrm{nm}$ photoacoustic instruments and photoelectric aerosol sensors in source-sampling of black carbon aerosol and particle-bound PAHs from gasoline and diesel powered vehicles, Environ. Sci. Technol., 39, 5398-5406, 2005.

Baumgardner, D., Kok, G. L., and Raga, G. B.: On the diurnal variability of particle properties related to light absorbing carbon in Mexico City, Atmos. Chem. Phys., 7, 2517-2526, 2007, http://www.atmos-chem-phys.net/7/2517/2007/.

Bond, T. C. and Bergstrom, R. W.: Light absorption by carbonaceous particles: an investigative review, Aerosol Sci. Technol., 40, 27-67, 2006

Brown, D. M., Wilson, M. R., MacNee, W., Stone, V., and Donaldson, K.: Size-dependent proinflammatory effects of ultrafine polystyrene particles: a role for surface area and oxidative stress in the enhanced activity of ultrafines, Toxicol. Appl. Pharmacol., 175, 191-199, 2001.

Bukowiecki, N., Kittleson, D. B., Watts, W. F., Burtscher, H., Weingartner, E., and Baltensperger, U.: Real-time characterization of ultrafine and accumulation mode particles in ambient combustion aerosols, J. Aerosol Sci., 33, 1139-1154, 2002.

Burtscher, H., Leonardi, A., Steiner, D., Baltensperger, U., and Weber, A.: Aging of combustion particles in the atmosphere - results from a field study in Zurich, Water Air Soil Poll., 68, 137147, 1993.

Choi, H., Jedrychowski, W., Spengler, J., Camann, D. E., Whyatt, R. M., Rauh, V., Tsai, W., and Perera, F. P.: International studies of prenatal exposure to polycyclic aromatic hydrocarbons and fetal growth, Environ. Health Perspectives, 114, 1744-1750, 2006.

de Foy, B., Caetano, E., Magaña, V., Zitacuaro, A., Cárdenas, B., Retama, A., Ramos, R., Molina, L. T., and Molina, M. J.: Mexico City basin wind circulation during the MCMA-2003 field campaign, Atmos. Chem. Phys., 5, 2267-2288, 2005, http://www.atmos-chem-phys.net/5/2267/2005/.

de Foy, B., Varela, J. R., Molina, L. T., and Molina, M. J.: Rapid ventilation of the Mexico City basin and regional fate of the urban plume, Atmos. Chem. Phys., 6, 2321-2335, 2006,

http://www.atmos-chem-phys.net/6/2321/2006/.

de Foy, B., Lei, W., Zavala, M., Volkamer, R., Samuelsson, J., Mellqvist, J., Galle, B., Martinez, A.-P., Grutter, M., Retama, A., and Molina, L. T.: Modelling constraints on the emission inventory and on vertical dispersion for $\mathrm{CO}$ and $\mathrm{SO} 2$ in the Mexico City Metropolitan Area using Solar FTIR and zenith sky UV spectroscopy, Atmos. Chem. Phys., 7, 781-801, 2007,

http://www.atmos-chem-phys.net/7/781/2007/.

de Foy, B., Fast, J. D., Paech, S. J., Phillips, D., Walters, J. T., Coulter, R. L., Martin, T. J., Pekour, M. S., Shaw, W. J., Kastendeuch, P. P., Marley, N. A., Retama, A., and Molina, L. T.: Basinscale wind transport during the MILAGRO field campaign and comparison to climatology using cluster analysis, Atmos. Chem. Phys., 8, 1209-1224, 2008,

http://www.atmos-chem-phys.net/8/1209/2008/.

Doran, J. C., Barnard, J. C., Arnott, W. P., Cary, R., Coulter, R.,
Fast, J. D., Kassianov, E. I., Kleinman, L., Laulainen, N. S., Martin, T., Paredes-Miranda, G., Pekour, M. S., Shaw, W. J., Smith, D. F., Springston, S. R., and Yu, X.-Y.: The T1-T2 study: evolution of aerosol properties downwind of Mexico City, Atmos. Chem. Phys., 7, 1585-1598, 2007,

http://www.atmos-chem-phys.net/7/1585/2007/.

Dzepina, K., Arey, J., Marr, L. C., Worsnop, D. R., Salcedo, D., Zhang, Q., Onasch, T. B., Molina, L. T., Molina, M. J., and Jimenez, J. L.: Detection of particle-phase polycyclic aromatic hydrocarbons in Mexico City using an aerosol mass spectrometer, Internat. J. Mass Spectrometry, 263, 152-170, 2007.

Eiguren-Fernandez, A., Miguel, A. H., Froines, J. R., Thurairatnam, S., and Avol, E. L.: Seasonal and spatial variation of polycyclic aromatic hydrocarbons in vapor-phase and $\mathrm{PM}_{2.5}$ in southern California and rural communities, Aerosol Sci. Technol., 38, 447-455, 2004.

Esteve, W., Budzinski, H., and Villenave, E.: Relative rate constants for the heterogeneous reactions of $\mathrm{NO}_{2}$ and $\mathrm{OH}$ radicals with polycyclic aromatic hydrocarbons adsorbed on carbonaceous particles. Part 2: PAHs adsorbed on diesel particulate exhaust SRM 1650a, Atmos. Environ., 40, 201-211, 2006.

Harley, R. A., Marr, L. C., Lehner, J. K., and Giddings, S. N.: Changes in motor vehicle emissions on diurnal to decadal time scales and effects on atmospheric composition, Environ. Sci. Technol., 39, 5356-5362, 2005.

Jedrychowski, W., Galas, A., Pac, A., Flak, E., Camann, D., Rauh, V., and Perera, F.: Prenatal ambient air exposure to polycyclic aromatic hydrocarbons and the occurrence of respiratory symptoms over the first year of life, European J. Epidemiol., 20, 775782, 2005.

Jiang, M., Marr, L. C., Dunlea, E. J., Herndon, S. C., Jayne, J. T., Kolb, C. E., Knighton, W. B., Rogers, T. M., Zavala, M., Molina, L. T., and Molina, M. J.: Mobile laboratory measurements of black carbon, polycyclic aromatic hydrocarbons and other vehicle emissions in Mexico City, Atmos. Chem. Phys., 5, 33773387, 2005, http://www.atmos-chem-phys.net/5/3377/2005/.

Johnson, K. S., Zuberi, B., Molina, L. T., Molina, M. J., Iedema, M. J., Cowin, J. P., Gaspar, D. J., Wang, C., and Laskin, A.: Processing of soot in an urban environment: case study from the Mexico City Metropolitan Area, Atmos. Chem. Phys., 5, 30333043, 2005, http://www.atmos-chem-phys.net/5/3033/2005/.

Kamens, R. M., Guo, Z., Fulcher, J. N., and Bell, D. A.: Influence of humidity, sunlight, and temperature on the daytime decay of polyaromatic hydrocarbons on atmospheric soot particles, Environ. Sci. Technol., 22, 103-108, 1988.

Kittleson, D. B., Watts, W. F., and Johnson, J. P.: Nanoparticle emissions on Minnesota highways, Atmos. Environ., 38, 9-19, 2004.

Kolb, C. E., Herndon, S. C., McManus, J. B., Shorter, J. H., Zahniser, M. S., Nelson, D. D., Jayne, J. T., Carnagaranta, M. R., and Worsnop, D. R.: Mobile laboratory with rapid response instruments for real-time measurements of urban and regional trace gas and particulate distributions and emission source characteristics, Environ. Sci. Technol., 38, 5694-5703, 2004.

Kwamena, N.-O. A., Staikova, M. G., Donaldson, D. J., George, I. J., and Abbatt, J. P. D.: Role of the aerosol substrate in the heterogeneous ozonation reactions of surface-bound PAHs, J. Physical Chem. A, 111, 11 050-11 058, 2007.

Lee, W. J., Wang, Y. F., Lin, T. C., Chen, Y. Y., Lin, W. C., Ku, C. C., and Cheng, J. T.: PAH characteristics in the ambient air of 
traffic-source, Sci. Total Environ., 159, 185-200, 1995.

Mantis, J., Chaloulakou, A., and Samara, C.: PM10-bound polycyclic aromatic hydrocarbons (PAHs) in the greater area of Athens, Greece, Chemosphere, 59, 593-604, 2005.

Marr, L. C., Kirchstetter, T. W., Harley, R. A., Miguel, A. H., Hering, S. V., and Hammond, S. K.: Characterization of polycyclic aromatic hydrocarbons in motor vehicle fuels and exhaust emissions, Environ. Sci. Technol., 33, 3091-3099, 1999.

Marr, L. C., Black, D. R., and Harley, R. A.: Formation of photochemical air pollution in central California 1. Development of a revised motor vehicle emission inventory, J. Geophys. Res., 107, 4047, doi:10.1029/2001JD000689, 2002.

Marr, L. C., Grogan, L. A., Wohrnschimmel, H., Molina, L. T., Molina, M. J., Smith, T. J., and Garshick, E.: Vehicle traffic as a source of particulate polycyclic aromatic hydrocarbon exposure in Mexico City, Environ. Sci. Technol., 38, 2584-2592, 2004.

Marr, L. C., Dzepina, K., Jimenez, J. L., Reisen, F., Bethel, H. L., Arey, J., Gaffney, J. S., Marley, N. A., Molina, L. T., and Molina, M. J.: Sources and transformations of particle-bound polycyclic aromatic hydrocarbons in Mexico City, Atmos. Chem. Phys., 6, 1733-1745, 2006,

http://www.atmos-chem-phys.net/6/1733/2006/.

Matter, U., Siegmann, H. C., and Burtscher, H.: Dynamic field measurements of submicron particles from diesel engines, Environ. Sci. Technol., 33, 1946-1952, 1999.

Maynard, A. D.: Estimating aerosol surface area from number and mass concentration measurements, Annals of Occupational Hygiene, 47, 123-144, 2003.

Miguel, A. H., Kirchsetter, T. W., Harley, R. A., and Hering, S. V.: On-road emissions of particulate polycyclic aromatic hydrocarbons and black carbon from gasoline and diesel vehicles, Environ. Sci. Technol., 32, 450-455, 1998.

Molina, L. T., Kolb, C. E., de Foy, B., Lamb, B. K., Brune, W. H., Jimenez, J. L., Ramos-Villegas, R., Sarmiento, J., ParamoFigueroa, V. H., Cardenas, B., Gutierrez-Avedoy, V., and Molina, M. J.: Air quality in North America's most populous city overview of the MCMA-2003 campaign, Atmos. Chem. Phys., 7, 2447-2473, 2007,

http://www.atmos-chem-phys.net/7/2447/2007/.

Molina, M. J., Ivanov, A. V., Trakhtenberg, S., and Molina, L. T.: Atmospheric evolution of organic aerosol, Geophys. Res. Lett., 31, L22104, doi:10.1029/2004GL020910, 2004

Muller, J. F., Hawker, D. F., and Connel, D. W.: Polycyclic aromatic hydrocarbons in the atmospheric environment of Brisbane, Australia, Chemosphere, 37, 1369-1383, 1998.

Ntziachristos, L., Polidori, A., Phuleria, H., Geller, M. D., and Sioutas, C.: Application of a diffusion charger for the measurement of particle surface concentration in different environments, Aerosol Sci. Technol., 41, 571-580, 2007.

Oberdorster, G.: Toxicology of ultrafine particles: in vivo studies, Phil. Trans. Royal Soc. London Ser. A, 7, 111-124, 2000.

Ott, W. R. and Siegmann, H. C.: Using multiple continuous fine particle monitors to characterize tobacco, incense, candle, cooking, wood burning, and vehicular sources in indoor, outdoor, and in-transit settings, Atmos. Environ., 40, 821-843, 2006.
Polidori, A., Hu, S., Biswas, S., Delfino, R. J., and Sioutas, C.: Real-time characterization of particle-bound polycyclic aromatic hydrocarbons in ambient aerosols and from motor-vehicle exhaust, Atmos. Chem. Phys., 8, 1277-1291, 2008, http://www.atmos-chem-phys.net/8/1277/2008/.

Salcedo, D., Onasch, T. B., Dzepina, K., Canagaratna, M. R., Zhang, Q., Huffman, J. A., DeCarlo, P. F., Jayne, J. T., Mortimer, P., Worsnop, D. R., Kolb, C. E., Zuberi, B., Marr, L. C., Volkamer, R., Molina, L. T., Molina, M. J., Cardenas, B., Bernabé, R. M., Márquez, C., Gaffney, J. S., Marley, N. A., Laskin, A., Shutthanandan, V., Xie, Y., Brune, W., Lesher, R., Shirley, T., and Jimenez, J. L.: Characterization of ambient aerosols in Mexico City during the MCMA-2003 campaign with Aerosol Mass Spectrometry: results from the CENICA Supersite, Atmos. Chem. Phys., 6, 925-946, 2006,

http://www.atmos-chem-phys.net/6/925/2006/.

Seibert, P., Kromp-Kolb, H., Baltensperger, U., Jost, D. T., and Schwikowski, M.: Trajectory analysis of high-alpine air pollution data, in: Air Pollution Modeling and its Application X, edited by: Gryning, S.-E. and Millan, M. M., Plenum Press, New York, 1994.

Siegmann, K., Scherrer, L., and Siegmann, H. C.: Physical and chemical properties of airborne nanoscale particles and how to measure the impact on human health, J. Molecular Structure (Theochem), 458, 191-201, 1999.

Stoeger, T., Reinhard, C., Takenaka, S., Schroeppel, A., Karg, E., Ritter, B., Heyder, J., and Schulz, H.: Instillation of six different ultrafine carbon particles indicates a surface area threshold dose for acute lung inflammation in mice, Environ. Health Perspectives, 114, 328-333, 2006.

Tang, D., Li, T.-Y., Liu, J. J., Chen, Y.-H., Qu, L., and Perera, F.: PAH-DNA adducts in cord blood and fetal and child development in a Chinese cohort, Environ. Health Perspectives, 114, 12971300, 2006.

Tran, C. L., Buchanan, D., Cullen, R. T., Searl, A., Jones, A. D., and Donaldson, K.: Inhalation of poorly soluble particles. II. Influence of particle surface area on inflammation and clearance, Inhalation Toxicol., 12, 1113-1126, 2005.

Velasco, E., Siegmann, P., and Siegmann, H. C.: Exploratory study of particle-bound polycyclic aromatic hydrocarbons in different environments in Mexico City, Atmos. Environ., 38, 4957-4968, 2004.

Volkamer, R., Jimenez, J. L., San Martini, F., Dzepina, K., Zhang, Q., Salcedo, D., Molina, L. T., Worsnop, D. R., and Molina, M. J.: Secondary organic aerosol formation from anthropogenic air pollution: Rapid and higher than expected, Geophys. Res. Lett., 33, L17811, doi:10.1029/2006GL026899, 2006.

Westerdahl, D., Fruin, S., Sax, T., Fine, P. M., and Sioutas, C.: Mobile platform measurements of ultrafine particles and associated pollutant concentrations on freeways and residential streets in Los Angeles, Atmos. Environ., 39, 3597-3610, 2005.

Zheng, M. and Fang, M.: Particle-associated polycyclic aromatic hydrocarbons in the atmosphere of Hong Kong, Water Air Soil Poll., 117, 175-189, 2000. 